\title{
What Values do Leisure Sports Create and What is Their Relationship to Competitiveness?
}

Authors' contribution:

A) conception and design of the study

B) acquisition of data

C) analysis and interpretation of data

D) manuscript preparation

E) obtaining funding

\section{Ágnes Szabó}

Budapest Corvinus University, Hungary

\section{ABSTRACT}

Sports play an increasingly important role in the economy and in society. Yet when it comes to the study of sports economics, most literature focuses on professional athletics; the topic of leisure sports receives scant attention on both the theoretical and the practical level, as Downward and his co-authors pointed out in 2009. This article will focus on leisure sports. Its goal is to highlight the values that leisure sports instill in individuals, companies, society and the economy, and to explore how leisure sports can make them more competitive. I will begin with a short conceptual definition of leisure sports and competitiveness, followed by a review of relevant academic literature. Finally, this paper will analyze the results of 31 qualitative in-depth interviews with business professionals, government officials, and representatives of civil society and university experts who specialize in sports business or sport sociology.

KEYWORDS leisure sports, value creation, competitiveness

\section{Introduction}

According to Nefiodow (2004), the declining numbers of spiritually and physically healthy people will be an obstacle to economic growth in the coming years. Up to this point, the Kondratyev Cycle has been characterized by the development of technology - steam engines, railways, steel, electronics, fossil fuels, automobiles, information technology - which has had numerous negative side effects on the environment and human health. By contrast, the driving force of the sixth Kondratyev Cycle is health and healthy people. Nefiodow identifies the cycle's important factors as leisure sports, tourism, health tourism, biotechnology, and pharmaceuticals.

The objective of this paper is to introduce - after briefly describing a conceptual definition of leisure sports and competitiveness - the role played by leisure sports in creating values for individuals, corporations, and society. The paper will employ academic literature and my empirical research. These values contribute to competitiveness on the individual, corporate, and societal levels; this paper shows these contributions, too. I chose this topic for additional reasons. First, leisure sports do not receive enough attention: most studies on sports economics deal with professional sports. Although leisure sports should receive the same or more 
attention, I would like to draw attention to them. Secondly, the economic impact of leisure sports is becoming more and more significant. I would like to show in this paper the relevant economic reasoning and economic factors. Moreover, in my opinion the key to raising the level of a nation's professional sports performance lies in leisure sports and the long-term development of such.

My research question was: "How do leisure sports create values for individuals, society and companies?" I also wanted to know: "Would the findings from local Hungarian interviewees coincide with the findings from (international) literature? Would my interviewees view leisure sports and its potential to create values in the same manner as international sports economists?"

\section{Methods}

My research is based on a review of academic literature and analysis of 31 qualitative in-depth interviews. The qualitative research was aimed at introducing and understanding the situation in Hungary, where we have incredibly little knowledge about leisure sports and leisure-sport economics. In this case, the sampling is based on theoretical intention, not representation. Qualitative sampling concerns an intentionally selected small sample that takes shape as the research progresses. I had to conduct interviews until I reached the "saturation point," i.e., a new interview could add no new information. In my research, I considered it important to seek out views from all three sectors of society: the interviewees include 10 members of civil organizations, 12 people from the business sphere, and 3 government representatives. I also asked for thoughts and opinions from 6 academics. Most of the interviews took place in 2011 and lasted 90-120 minutes. In selecting the interview subjects, I employed the criterion, opportunistic, and snowball sampling methods (Miles \& Huberman, 1994, cited by Bokor, 2000). I analyzed the interviews using the Nvivo software program.

\section{Review of the academic literature}

In this chapter I write about the concepts, followed by the micro level (individual and company) and macro level value-creation of leisure sports.

\section{The concept of leisure sports and competitiveness}

In economic terms, the consumers of leisure sports are amateur athletes who partake in physical activity during their free time in order to reap the positive effects. The academic literature describes three general approaches toward conceptualizing leisure sports. The first stresses that the activity must take place during free time, must be voluntary, and must be organized - passive participation is entirely excluded. The second approach excludes elements that apply to professional sports (working, earning money, competition, and recording scores and statistics). The third approach lists the various sporting activities and their effects (see more details: Szabó, 2012). This conceptual system is by no means definitive; other interpretations of "leisure sports" are certainly possible. In my own understanding, leisure sports can be any physical or active recreational activity whose goal is to maintain or restore health, recreation, amusement, or to achieve a feeling of physical and spiritual well-being, both during and after the exercise. I can participate in sports at fitness centers that provide equipment and services on a for-profit basis; at facilities run by state governments, municipalities or communities; in public parks; with civil society groups (organizations); or even at home. Facilities play a very important role in leisure sports' consumption (Wicker et al., 2009; Pawlikowska-Piechotka \& Sawicka, 2013). The prerequisites for the consumption of leisure sports include (Budai, 1999): sufficient free time, adequate living standards, money, and the right attitude. Laki \& Nyerges (2004) stressed the same three factors. In my opinion, the most important element is the right attitude, which is much more difficult to measure than the factors of time or money. In her study on the sporting habits of Hungarian youth, Pataki (2007) established that attitudes directly affect people's inclinations to actively 
consume leisure sports, while money has only an indirect impact. Meanwhile, research by Paár (2010) has suggested that spending on sports is considered a luxury good in Hungary.

The concept of competitiveness is not easy to define. According to the definition originally formulated by the OECD and later used in European Union documents, competitiveness should be understood as the ability of companies, industries, regions, nations, and supranational regions to generate, all while being and remaining exposed to international competition, relatively high factor income and factor employment levels on a sustainable basis. (Framework Conditions for Industrial Competitiveness, 1994, cited in Némethné, 2010) Competitiveness can be understood on the micro, mezzo, and macro levels. On the micro level (individuals, households, and companies), individuals are competitive if their productivity is high and they can continuously supply products and services on more attractive terms than the competition. On a national economic level, a country can be regarded as competitive if it provides its citizens with opportunities to attain high and improving standards of living. Here, too, productivity is behind the concept of competitiveness, as well as at the mezzo level as regards industrial competitiveness. The various indexes that assess countries' economic competitiveness bring together several significant hard and soft factors. The International Institute for Management Development (IMD)'s World Competitiveness Yearbook and the World Economic Forum's (WEF) Global Competitiveness Report are the oldest and widest-ranging annual reports (Czakó, 2004). The European Union's analytical framework places living standards at the top of the competitiveness pyramid; according to the EU, employment and productivity levels determine the quality of living standards on a societal level (Chikán \& Czakó, 2009). At first glance, it may be difficult to understand what type of relationship leisure sports has with competitiveness. However, leisure sports may have an important impact on the factors that were in the definitions of competitiveness: productivity, general welfare, standards of living, per-capita GDP, employment, and the rates of improvement in all these factors. Having looked through the determinant indicators in the macroeconomic sections of the competitiveness indexes, there is a link between these two concepts (Table 1).

Table 1: Possible links between competitiveness and leisure sports

\begin{tabular}{|c|c|c|}
\hline Individual level & Business level & Macro level \\
\hline \multicolumn{3}{|l|}{ Productivity and productivity growth } \\
\hline \multicolumn{3}{|l|}{ Quality of human capital } \\
\hline \multicolumn{3}{|l|}{ Health status } \\
\hline \multirow[t]{2}{*}{ Life expectancy and quality of life } & & Life expectancy and quality of life \\
\hline & Amount, effici & ctivity of available workforce \\
\hline \multirow[t]{4}{*}{ General welfare/living standards } & & GDP, per-capita GDP/general welfare/ \\
\hline & & /living standards and the growth thereof \\
\hline & & Mortality rate \\
\hline & & $\begin{array}{l}\text { Social capital, social cohesion, safe and } \\
\text { secure social environment }\end{array}$ \\
\hline
\end{tabular}

Source: own table based on IMD (2007) and WEF (2010).

The following review of academic literature will analyze leisure sports' effects on the micro (individual and business) level, followed by an analysis of the macro level. I will demonstrate how leisure sports can make individuals, companies, and the entire economy more competitive.

\section{Value-creation on micro level in the academic literature}

When the purpose of sports is the maintenance of bodily and spiritual health, then sports can be viewed as a kind of consumer durable good (Nagy, 1996; Downward et al., 2009). At the same time, regular participation in sports contributes to the development and maintenance of health, well-being, and long life, both in the present and the future (see the Health Belief Model of Glanz \& Rimer, 1995, cited in Henderson, 2009). Positive effects include: maintaining bodily health, maintaining spiritual health, maintaining high spirits, improved ability to perform intellectual and physical work, development of positive self-image, body-weight management, stronger character and self-will, and stronger public morale. It has been 
scientifically proven that regular physical activity lowers the occurrence of heart and cardiovascular diseases. Physical activity reduces the risk of cardiovascular illness and type 2 diabetes by improving glucose metabolism and lowering body fat and blood pressure (Lechner, 2009; Oakley \& Rhys, 2008). Since 1990, more than 1,500 scientific studies have been published on the relationship between physical activity and health (Nana et al., 2002). Sports develop skills and abilities that are transferable to both the workplace and other areas of life. Several theoretical models can be applied to this approach, such as the Theory of Planned Behaviour, Social-cognitive, Self-efficacy, Commitment, and Self-determination models (Henderson, 2009). Another study conducted in England found that students who regularly participated in sports achieved stronger academic results, were less likely to commit truancy, and exhibited better behavior (Oakley \& Rhys, 2008). Naturally, leisure sports not only help people preserve their health, they also provide consumers with enjoyment, excitement, and a feeling of well-being. These advantages are limited to the time period when people are actually participating in sports, so in this case, leisure sports can be considered as a consumer non-durable good (Nagy, 1996). Other such advantages include the thrill of the game, the love of competition, the love of winning, enjoyment, excitement, relaxation, liberation, well-being, and the pleasure of spending time with family and friends (see the enjoyment model of Henderson \& Ainsworth, 2000, cited in Henderson, 2009) and Social Support Model (Seefeldt et al., 2000, cited in Henderson, 2009). The sports that allow an athlete to improve or maintain his/her health should not be viewed as merely a consumer durable good, but also as a capital asset (Nagy, 1996; Lechner, 2009; Downward et al., 2009). In this case, a sport's utility is not specifically in its impact on human health, but in the fact that healthier people are capable of producing more and are more reliable members of the work force; consequently, they will be able to earn more and achieve a higher standard of living. Lechner (2009), who used German panel data from 1984-2006, provided empirical evidence of physical activity's impact on income. People who participated in sports earned an average of $€ 100$ more per month. An additional advantage of healthier individuals is reduced spending on health care. Gémes (2009), using Hungarian representative health-study data from 2002, provided empirical evidence of physical activity's impact on the aforementioned facts. People who were inactive could not be reliable members of work force because they could not work effectively and they were on sick leave more often than the physically active workers. They also spent more days in hospitals than active people (cited in Ács et al., 2011). Still, the latest empirical research shows that more than $60 \%$ of Hungarians do not participate in sports with suitable regularity (Polányi, 1998; Gáldi, 2002; Gáldi, 2004; KSH, 2006; Földesiné, 2008; Eurobarometer, 2010; Gál, 2010; Király \& Gál, 2010). A bigger problem is that young people do not do enough sports, too. (For more on consumer habits on sports of young people in Hungary, see Polányi, 1998; Laki \& Nyerges, 1999; Pluhár et al., 2003; Neulinger, 2007; Pataki, 2007; Perényi, 2010, Edvy, 2013). The situation is similar in the Czech Republic (Sekot, 2010) and in Poland (Dabrowski \& Radiuk-Strzeżek, 2010).

The cumulative positive experiences of companies whose staffs participate in leisure sports are perceptible on the national economic level - and in my opinion, they are hardly negligible in individual corporations' profit statements, either. If employees participate in sports, then the amount that a company spends on sick-leave compensation decreases, there are fewer absences from work and there are fewer illnesses and workplace accidents. Moreover, healthier people perform better physically and intellectually; they are more efficient, more productive, and express greater levels of satisfaction and motivation. Sports help develop numerous abilities that can be transferred to the workplace (Neck et al., 2000; Nana et al., 2002; McDowell-Larsen et al., 2002; Lechner, 2009). According to surveys conducted by Canadian researchers in the early 1990s, companies that offered exercise programs increased productivity, reduced the number of absences, lowered employee turnover rates, and recorded fewer workplace accidents. The study also found that a $25 \%$ increase in physical activity among workers on a societal level resulted in $0.25-1.5 \%$ increase in workforce productivity (Nana et al., 2002). In 1985, the automobile manufacturer Daimler launched its Wellness Program. Ten years later, the company calculated it was saving $\$ 16$ per worker every month, while workers were spending \$100-200 less on healthcare per year (Smith \& Westerbeek, 2007). According to the EU, every euro that a company invests in workplace health reaps savings of $€ 2.5-4.8$. It 
would be truly worthwhile to spend more on workplace sports as a part of health improvement programs and to treat workplace sports as an investment. Perhaps then the EU would not lose 146 million workdays to illness every year. Another dimension is the role sports can play in corporate social responsibility (CSR) programs. Companies could contribute to the (internal and external) community's well-being by organizing leisure sports events or providing support and sponsorship. This would also have a positive impact on the company's reputation and image (Mallen \& Adams, 2008).

\section{Value creation on macro level in the academic literature}

If people do sports during their free time, their health will improve and they will pose a lower burden on healthcare and social security systems. Ács et al. (2011) estimate that a 10\% reduction in the level of physical inactivity in Hungary could reduce spending on inactive sick-leave pay by an average of HUF 1.8 billion a year, which means an annual average savings of 573,175 sick-leave days. In addition to reducing the total cost of treatment, it would also be possible to avoid loss of income due to sickness; moreover, good physical condition could lead to greater productivity. According to Oakley \& Rhys (2008) healthcare costs would be $Ł 8.2$ billion less by reducing the number of inactive people by $10 \%$. This sum of money is $5 \%$ of all healthcare costs in England. According to Harmath \& Czárán (2006), better health standards among the population affect the economy and society through four factors: higher productivity, a better supply of workers, stronger skills, and increased capacities in physical and intellectual capital. It is possible to identify three kinds of spending related to poor health: direct, indirect and "soft costs." Direct costs include spending related to illness and recovery, as well as the total costs of treatment, sick-leave pay, and disability pension. Indirect costs cover lost production due to sickness. They also include losses stemming from reduced output by workers with less-than-optimal health (this is also known as "presenteeism," meaning the employee reports for work, but is less productive and efficient). Losses from presenteeism can be several times greater than losses caused by worker absences. The "soft costs" of sickness are those unquantifiable costs related to pain, suffering, and other, psychological burdens stemming from illness (Kollányi \& Imecs, 2007). According to data from Andreff \& Szymanski (2006) and Bloom et al. (2005), the cost of caring for inactive people in Canada amounted to 2.1 billion Canadian dollars, or $2.5 \%$ of direct healthcare spending, plus an additional 3.7 billion Canadian dollars in indirect costs. The direct and indirect costs related to obesity amount to 4.3 billion dollars a year. Canadian researchers (Staines et al., 2003) demonstrated that for every dollar the state devotes to a person's exercise, it saves CAD 2-5 dollars over 10 years. The American disease-prevention center expressed similar views when it acknowledged that leisure sports are a good investment: "For every dollar they spend promoting physical activity, they reap three". In a paper entitled "Health and development through physical activity and sport" (2003), the World Health Organization established that every dollar invested in physical activity brings savings of $\$ 3.20$ in health care.

Life expectancy is decreasing due to poor health conditions resulting from a lack of physical activity. This means people spend less time in the labor force and produce less for the economy. It is difficult to measure the societal value of life in numbers, but it is indisputable that society also suffers losses. According to data from the American National Institutes of Health, physical inactivity is the reason behind $16.6 \%$ of total mortality and terminal illness. Through leisure sports, it is possible to reduce the rate of mortality and disability (Staines et al., 2003). Physical inactivity is responsible for an estimated 600,000 deaths a year in the European Union; it also causes annual losses of 5.3 million years of healthy living due to premature disability and deteriorating health (Edwards \& Tsouros, 2006). According to calculations by Nordhaus (2002, cited in Ács et al., 2011), a preserved year of life is worth \$3 million. Barro considers the population's health to be one of the most important indicators of economic output and growth (Barro, 1997, cited in Ács et al., 2011). An increase of about $1 \%$ in life expectancy boosts GDP by $4 \%$ (Bloom \& Canning, 2000). The OECD adds that productivity is one of the most important components of human capital (Chikán \& Czakó, 2009). Sports are a sensible way for people to spend their free time and burn off spare energy. By increasing participation in leisure sports, boredom decreases, self-affirmation and self-discipline increase, and positive behavior develops in a positive milieu; therefore, levels of crime and hooliganism will drop, as will the cost 
of keeping public order. This will boost morale among the other members of society (Berrett et al., 1993; Oakley \& Rhys, 2008). Sports encourage dialogue between cultures and help to combat discrimination in its various forms (Goodchild et al., 2000). Hence, athletics can facilitate community formation and social cohesion and help bolster community spirit. They can be a force for national and cultural identity formation and can contribute to social development at the local level (Chalip, 2006; Oakley \& Rhys, 2008). Leisure sports impact the national economy by increasing its capacity for output, productivity, and GDP. Leisure sports also create jobs, boost spending, and generate tax revenues (Goodchild et al., 2000; Berrett, 2001; Nana et al., 2002; Staines et al., 2003; Berrett \& Reimer, 2005; Chalip, 2006; Andreff \& Szymanski, 2006). Leisure sports are an increasingly important part of tourism. Revenue sources related to tourism include health tourism; event tourism from various leisure sporting events such as street races, swimming across lakes, and multicultural youth events; and leisure activities within the framework of resort tourism (equestrian, bicycle, or golf tourism). Leisure sports can also generate significant revenues through related travel, not just for purposes of tourism. In the United Kingdom, sports-related travel accounts for $10 \%$ of total leisure travel (Gratton \& Taylor, 2000). Human capital plays a decisive role in explaining the differences in competitiveness between the economies of developed and less-developed countries (Palócz, 2006). Suhrcke et al. (2005) express similar views in a 2005 study for the European Commission. There is ample proof that human capital and job training increase in tandem with improvements in health. The best way a person can develop and maintain his/her health is by DOIng sports in his/her free time. Palócz (2006) asserts that a higher standard of health is at once a result and a cause of economic competitiveness. Thus health and sports have a close symbiotic relationship with national economic competitiveness; when combined with appropriate economic and social policies, health and sports can mutually reinforce one another. Because human capital is an endogenous component of economic growth, it can be influenced to some extent through public policy tools (Chikán \& Czakó, 2009). In Hungary, "a serious modification of sport policy does not mainly depend on the lack of financial recourses but on the lack of a strong determination of the Government" (Földesiné, 2010).

\section{Results of empirical research}

The following pages will offer a brief overview of the results of the 31 in-depth interviews. This includes a comparison of the opinions of important players in the Hungarian leisure-sports industry with the findings of the academic literature listed above. In this section, I sought to answer my research question: "How do leisure sports create values for individuals, society and companies?" The topic "company sports" was very popular among my interviewees: analysis with Nvivo software revealed 149 paragraphs that included this topic. The value creation for companies and the company sports are in the limelight.

The interview subjects reinforced the health model's findings that regular physical activity, both now and in the future, contributes to the development and maintenance of bodily and spiritual health. They heavily emphasized the factors related to spiritual health as well as the preservation of physical health. One particularly important example of value-creation related to bodily health was weight control. The interview subjects, especially the civil-society representatives, stressed the importance of development of skills and abilities as discussed in the literature review. The idea that leisure sports are consumer non-durable goods received as much emphasis as the view that leisure sports are consumer durable goods. The interviewees stressed that leisure sports contribute to momentary well-being and cited momentary happiness, enjoyment, and excitement as motivational factors; that is, people do not do sports in their free time for their long-term health, but for their short-term enjoyment. Momentary good feeling is not only attained through exercise itself, but through the game and the thrill of victory. Moreover, the value of victory comes not only from our ability to vanquish opponents, but also from within ourselves - the feeling that we have exceeded our personal boundaries. Individual accomplishments fill people's hearts with pride, and this pride may not be just a momentary feeling. According to the people I interviewed, the feeling of pleasure can be a useful incentive for exercise, and it is important for school physical education programs to teach the kinds of exercise that make students happy. Healthier workers perform better and are more reliable. Representatives 
of the business sector said employers are looking for healthy, reliable employees who are capable of handling large burdens. Interestingly, some members of the management class (a class which is usually highly educated and lives in good financial condition) regularly take part in sports. Yet they do so "merely" because they like the challenging tempo, to live up to expectations, to look good, to be fit, and to avoid having to struggle with excess weight. A sporty lifestyle allows them to perform at their maximum level on a daily basis. The key to increasing leisure sports activities in Hungary may be found in formulating new attitudes, education, and public-service messages. Hungarians are still not aware that DOIng sports during their free time will lower the amount they spend on healthcare due to their improved health status. To date, there is no recognition among the Hungarian population that it is cheaper to spend money on sports than on doctors and medicine.

The interviewees (mostly university experts) discussed the same important corporate-level valuecreation factors that were described in the literature review: a healthy labor force, low rate of absenteeism, higher levels of motivation, satisfaction, and productivity. Workplace sports are in the interest of both employer and employee. They represent a win-win situation where all parties benefit. A workplace sports program is a long-term investment that will not yield results from one day to the next. Companies must continuously devote resources, but these will definitely reap rewards in the long run. Companies can demonstrate corporate social responsibility through leisure sports. These activities help the firms build up a positive image and create corporate community spirit. In addition to the findings of the academic literature, the interviewees from the business community added that companies can "draw in" more people by sponsoring leisure sports than by sponsoring professional sports, which "supports" relatively few people, i.e., the team and its loyal fans. By sponsoring leisure sports, firms can establish a more direct, more active relationship; it allows them to get closer to the people (community involvement). According to the businesssector representatives (and some civil-society representatives), not only are there no Hungarian surveys that demonstrate sports' beneficial impact on companies, there are also very few exercise programs. Frequently mentioned exceptions include Coca-Cola's "Testébresztö" (Body-awakening) Program and the STEP Program at Mol, a Hungary-based oil refiner. At present, company sports are an up-and-coming topic that has not yet been remotely touched - yet there are opportunities in this field.

Concrete types of workplace sports include:

- gyms, fitness centers, organized classes, organized championship games (very few companies offer such programs),

- family days and sports days; company Olympics (1 day out of 365),

- opportunities to participate in events for free or at discounted rates. These could be companyorganized events, company-sponsored events, or "neutral" events that are neither organized nor sponsored by the company,

- allowing workers to use "Cafeteria", a Hungarian employee-benefits system, for sports activities; opportunities for workers to participate in athletics through company contracts with service providers,

- making it easier for workers to cycle to work, building bicycle-storage units, buying bikes for workers.

Innumerable problems crop up in relation to workplace sports, and these represent obstacles. Some problems are exterior, while others are within the companies themselves: there is a lack of laws, regulations, and tax breaks to support workplace leisure sports. The existing support structure - e.g., the abovementioned "Cafeteria" system and recreation card - is not sufficient. It would be preferable to expand these opportunities instead of cutting them. Furthermore, the general social environment and culture are not favorable: there are not enough leisure sports within a company, and there are not enough leisure sports outside the company, either. Companies do not know how to reach out to their employees who, as it stands, do not exercise. Rather than having a goal of promoting exercise among those people who already like to work out and participate in sports, companies should be targeting inactive people. Companies are incapable of reaching out to the inactive masses. They have neither the methods nor the personnel. Most companies approach sports days with a "let's get it over with" attitude. There is a lack of a long-term approach, awareness, and true exercise programs. It is not entirely clear which department within a firm should oversee 
company sports, who should be responsible, who should provide the funding, or who will be able to claim credit for the program. An Alliance for Company Sports exists on paper, but it is not actually in operation. That is a shame, because it would be a very good platform for collecting and exchanging best practices, expertise and concepts - the kind that are lacking in Hungary today. It is particularly important for company managers to get personally involved. In present-day Hungary, a commitment from a manager matters much more than spelling out the quantifiable and rational advantages that can be useful for business purposes.

When it came to macro-level value creation, the interview subjects mostly spoke about healthcare, reducing healthcare costs, and mitigating the loss of income due to illness. The issue of time horizons represented an incredibly important dimension: spending on leisure sports is a long-term investment. The key to solving this would be to adopt a long-term mode of thinking. Another key factor would be to concentrate more on disease-prevention rather than treating people once they become sick. Leisure sports would be a prime tool for preventing illness. Leisure sports are also an excellent tool for developing social capital. First, it allows people to burn off excess energy, which thereby lowers the cost of preserving public order. Second, it facilitates community formation and social cohesion.

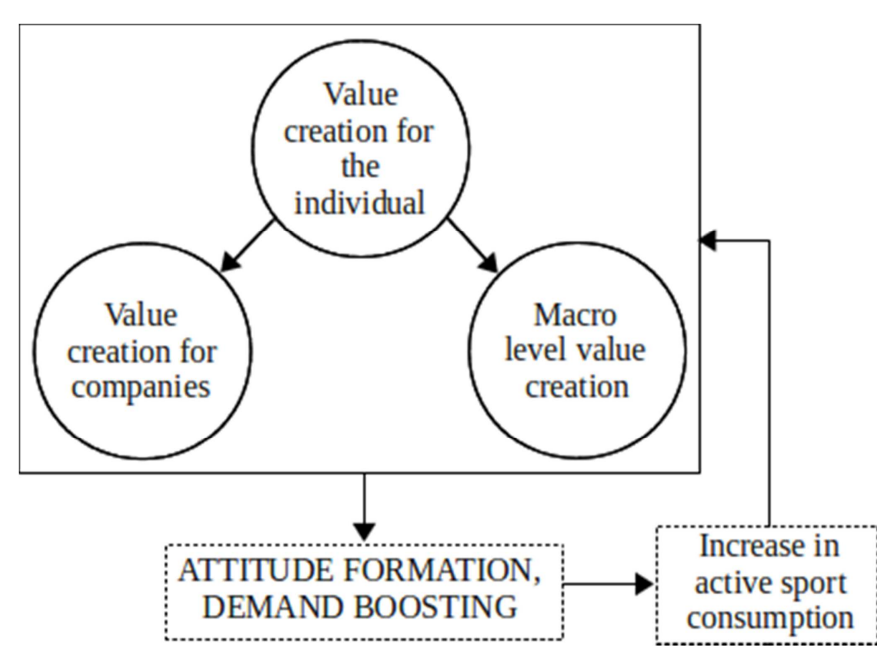

Figure 1. Value-creation spiral in leisure sports Source: Szabó (2012).
All in all, the individual value-creation factors (such as better health conditions, transferable skills, and being a more reliable worker) have an effect both on the company and on the society. The communication of the valuecreation factors could help in the attitude formation and boosting demand. It is especially true in the case of the individual value-creation factors, and the value-creation factors for companies. Through attitude formation, the level of active sports consumption will increase, which in turn will open the opportunity to create values in the individual, corporate and macro levels. In other words, a positive value-creation spiral will be set in motion (see Figure 1).

Table 2 summarizes the micro and macro value-creation factors of leisure sports. It shows whether a given factor can be used to promote national economic competitiveness, and if so, how.

\section{Conclusion}

My interviewees spoke about the same individual value-creation factors discussed in the academic literature. In their view, the problem is that a large part of the population does not recognize these principles; members of society are not yet aware of the value-creation factors inherent in leisure sports. Hence, there is a major need for education and attitude formation, using these value-creation factors. My interview subjects also discussed many of the corporate-level value-creation factors that appeared in the literature review, but did not broach the idea that leisure sports can help participants develop skills that are beneficial in the workplace. The business-sector representatives emphasized the idea that support for leisure sports - adopting company sports programs, setting up or sponsoring events - presents an opportunity to demonstrate social responsibility, to build up a positive image both internally and externally, to reach out to a greater number of people, and to get closer to their target groups. Leisure sports also represent an excellent tool for promoting community involvement. At present, however, the question of whether or not a company embraces leisure sports - either through an employee athletics program or by sponsoring leisure sports - depends on the managers' personal preferences and their level of commitment. There is a great potential in this field, not only in the present but also in the future, that the workplace could be an important place of attitude formation and boosting demand towards leisure sports involving new customers. When discussing value-creation 
factors on the macro level, my interview subjects focused on health and healthcare expenses. Only one interviewee talked about leisure sports' capacity to create jobs and generate revenues (tax receipts). Several interviewees held out the Swedes and Finns - who are at the top of the various indexes and also do more sports than any other European nation - as role models for Hungarians.

Table 2. The potential of leisure sports to create values on the micro and macro levels and their contribution to national economic competitiveness

\begin{tabular}{|c|c|}
\hline Value Creation through Leisure Sports & Contribution to National Economic Competitiveness \\
\hline $\begin{array}{l}\text { Micro level } \\
\text { Individual factors }\end{array}$ & \\
\hline $\begin{array}{l}\text { Maintenance / development / restoration of bodily health* } \\
\text { Maintenance / development / restoration of spiritual health* }\end{array}$ & $\begin{array}{l}\text { Development of human capital (health conditions); } \\
\text { increases in life expectancy, quality of life, productivity, } \\
\text { and GDP; reduction in the mortality rate }\end{array}$ \\
\hline Development of transferable abilities and skills* & $\begin{array}{l}\text { Development of human capital (knowledge, } \\
\text { capabilities); increase in worker productivity }\end{array}$ \\
\hline $\begin{array}{l}\text { Feelings of momentary enjoyment, excitement and } \\
\text { happiness } \\
\text { Factor in workforce reliability / attaining higher individual } \\
\text { income* } \\
\text { Lower individual healthcare expenses* } \\
\text { Corporate factors }\end{array}$ & Higher worker productivity \\
\hline $\begin{array}{l}\text { Lower company sick-leave expenses* } \\
\text { Fewer workplace absences / illnesses / accidents* } \\
\text { Higher level of achievement (more satisfied, motivated } \\
\text { workers)* } \\
\text { Development of transferable abilities/skills that are } \\
\text { important for work* } \\
\text { Demonstrating social responsibility through leisure sports } \\
\text { (to both workers and the community) } \\
\text { Macro level }\end{array}$ & - \\
\hline Lower healthcare and sick-pay expenses* & $\begin{array}{l}\text { Improved health conditions } \rightarrow \text { increased economic } \\
\text { productivity, GDP }\end{array}$ \\
\hline $\begin{array}{l}\text { Reduced loss of income due to illness* } \\
\text { Lower mortality and disability rates, increased life } \\
\text { expectancy* }\end{array}$ & $\begin{array}{l}\text { Higher economic productivity, GDP } \\
\text { Higher economic productivity, GDP and life } \\
\text { expectancy, reduced mortality rate }\end{array}$ \\
\hline $\begin{array}{l}\text { Reduced crime, hooliganism, vandalism, and lower spending } \\
\text { on keeping public order }\end{array}$ & $\begin{array}{l}\text { Development of social capital - building a safe and } \\
\text { secure social environment }\end{array}$ \\
\hline Community development & Development of social capital (social cohesion) \\
\hline New jobs & Higher economic productivity, GDP \\
\hline Additional tax revenues & - \\
\hline $\begin{array}{l}\text { Higher business revenues from increased consumption of } \\
\text { sports tourism, travel and transport }\end{array}$ & \\
\hline
\end{tabular}

Note: *denotes only in the case of DOIng physical activity regularly.

Source: Szabó (2012).

Leisure sports can also have a role in mobilizing competitiveness and numerous value-creation factors can be linked to national economic competitiveness. Individuals, companies, and the state must all devote more resources to leisure sports so that they all can reap the benefits as well as take the opportunity to instill new, competitive values in society.

\section{REFERENCES}

Ács, P., Hécz, R., Paár D. \& Stocker M. (2011). A fittség (m)értéke /The Value of fitness/. Közgazdasági Szemle /Economic Review/, 58(4), 689-708.

Andreff, W., Szymanski, S. (2006). Handbook on the economics of sport. UK: Edward Elgar Publishing Inc.

Berrett, T. (2001). The economic significance of amateur sport and active recreation in Edmonton in 2000. Edmonton:

Caminata Consulting. Retrieved November 21, 2006, from

http://www.edmontonsport.com/pdf_folder/news_submissions/EconomicSignificance.pdf 
Berrett, T., Reimer, R. (2005). The economic significance of amateur sport in the city of Calgary in 2002. Retrieved November 21, 2006, from http://www.calgary.ca/docgallery/bu/recreation/sports_updates/economic_final_report.pdf

Berrett, T., Slack, T., Whitson, D. (1993). Economics and the Pricing of Sport and Leisure. Journal of Sport Management, 7(3), 199-215.

Bloom, D., Canning, D. (2000). Health and wealth of nations. Science, 287(5446), 1207-1208.

Bloom, M., Grant, M., Watt, D. (2005). Strengthening Canada. The socio-economic benefits of sport participation in Canada. Retrieved November 21, 2006, from

http://vancouver.ca/parks/activecommunity/pdf/SportsParticipation.pdf

Bokor, A. (2000). Szervezeti kultúra és tudásintegráció: A termékfejlesztés problémája /Organizational Culture and Knowledge Integration: The Case of New Product Development/. Doktori (PhD) értekezés, BKÁE, Budapest /PhDthesis, Budapest University of Economic Sciences/.

Budai, E. (1999). Sport(t)örvényben fuldokolva /Drawing in the sports law/. Új Folyam /New Stream/, 8(3-4), 20-33.

Chalip, L. (2006). Toward a distinctive sport management discipline. Journal of Sport Management, 20(1), 1-21.

Chikán, A., Czakó, E. (2009). Versenyben a világgal. Vállalataink versenyképessége az új évezred küszöbén /Competitiveness of our companies in the new century/. Budapest: Akadémiai Kiadó /Academic Publisher/.

Czakó, E. (2004). Miért versenyképes a versenyképesség? /Why could competitiveness be competitive?/ In E. Czakó, I. Dobos and A. Köhegyi (2004). Tanulmányok Chikán Attila tiszteletére /Studies in honour of Attila Chikán/. Budapest: BKÁE, Vállalatgazdaságtan Tanszék /Department of Business Economics of Budapest University of Economic Sciences/.

Dąbrowski, A., Radiuk-Strzeżek, J. (2010). Physical Recreation of Students of Selected Warsaw Non-Public Higher Education Institutions - Preferences and Motivations. Physical Culture and Sport. Studies and Research, 48(1), 99-109. DOI: $10.2478 / \mathrm{v} 10141-010-0010-4$.

Downward, P., Dawson, A., Dejonghe, T. (2009). Sports Economics. Theory, evidence and policy. China: Elsevier.

Edvy, L. (2013). Quality of Life Indicators of University Students in Hungary. Physical Culture and Sport. Studies and Research, 58(1), 53-60. DOI: 10.2478/pcssr-2013-0012.

Edwards, P. \& Tsouros, A. (2006). The Solid Facts: Promoting physical activity and active living in urban environments: The Role of Local Governments. Geneva: WHO European Office.

Eurobarometer (2010). Sport and Physical Activity. Retrieved March 21, 2012, from http://ec.europa.eu/sport/library/documents/d/ebs_334_en.pdf

Földesiné, Sz.Gy. (2008). Sportfogyasztás, mint a kulturális fogyasztás válfaja /Sports cunsumption as a way of cultural consumption/ In Sz.Gy. Földesiné, A. Gál \& T. Dóczi (Eds.), Társadalmi riport a sportról 2008 /Social report about sports in 2008/ (pp. 41-89). Budapest: ÖTM-MSTT.

Földesiné, Sz.Gy. (2010). Social Exclusion/Inclusion in the Context of Hungarian Sport. Physical Culture and Sport. Studies and Research, 50(1), 44-59. DOI: 10.2478/v10141-010-0023-z.

Gál, A. (2010). Elite Sport and Leisure Sport in Hungary: The Double Trouble. Physical Culture and Sport. Studies and Research, 49(1), 72-77. DOI: 10.2478/v10141-010-0018-9.

Gáldi, G. (2004). Szabadidőstruktúra és fizikai reakció Magyarországon 1968-2000 között életmód-időmérleg vizsgálatok tükrében. /Leisure time structure and physical recreation in Hungary between 1968-2000 in the light of time-use research/. PhD értekezés. Semmelweis Egyetem Testnevelési és Sporttudományi Kar, Budapest /PhD-thesis, Semmelweis University Faculty of Physical Education and Sport Sciences/.

Gáldi, G. (2002). Fizikai aktivitás Magyarországon az ezredfordulón /Physical activity in Hungary at the Millennium/. Magyar Sporttudományi Szemle /Hungarian Review of Sport Science/, 16-18, 3-4.

Goodchild, M., Harris, F., Nana, G., Russel, S. (2000). The growing business of sport and leisure. Retrieved November 21, 2006, from http://www.ausport.gov.au/fulltext/2000/hillary/growing_business_2000.asp

Gratton, C., Taylor, P. (2000). Economics of sport and recreation. London: E and FN Spon.

Henderson, K.A. (2009). A paradox of sport management and physical activity interventions. Sport Management Review, 12(2), 57-65.

Haramth, Gy., Czárán, E. (2006). Az egészség szerepe az Európai Unió országainak gazdaságában /The role of health in the economies of the EU countries/. Egészségügyi Gazdasági Szemle /Health Economics Review/, 44, 14-17.

Király, I., Gál, A. (2011). From Grass Roots to World Class (A Strategy for Delivering Physical Activity). Physical Culture and Sport. Studies and Research, 51, 30-44. DOI: 10.2478/v10141-011-0003-y.

Kollányi, Zs., Imecs, O. (2007). Az egészség - befektetés /Health-investment/. Budapest: DEMOS Magyarország Alapítvány/DEMOS Hungary Foundation/. 
KSH. (2006). Az átmenet évei, az átmenet tényei /The years of transition, and the facts transition/. Budapest: KSH /Central Statistical Office Budapest/.

Laki, L. \& Nyerges, M. (2004). A fiatalok sportolási szokásainak néhány társadalmi összefüggése /Social aspects of the youth sports/. Magyar Sporttudományi Szemle /Hungarian Review of Sport Science/, 2-3, 5-15.

Lechner, M. (2009). Long-run labor market and health effects of individual sports activities. Journal of Health Economics, 28(4), 839-854.

Mallen, C., Adams, L.J. (2008). Sport, recreation and tourism event management. Oxford: Elsevier.

McDowell-Larsen, S.L., Kearney, L., Campbell, D. (2002). Fitness and leadership: is there a relationship? Regular exercise correlates with higher leadership ratings in senior-level executives. Journal of Managerial Psychology, 17(4), 316-24.

Nagy, P. (1996). A sport és a rekreáció közgazdaságtana /The economics of sports and recreation/. Budapest: BKE.

Nana, G., Sanderson, K., Goodchild, M. (2002). Economic impact of sport. Wellington: Business and Economic Research Ltd.

Neck, C.P., Mitchell, T.L., Manz, C.C., Cooper, K.H., Thompson, E.C. (2000). Fit to lead: is fitness the key to effective executive leadership? Journal of Managerial Psychology, 15(8), 833-40.

Nefiodow, L.A. (2004). Der Gesundheitsmarkt - die Wachstumslokomotive im 21. Jahrhundert. Paper presented at the IV. Unternehmerforum Wittlich, Wittlich, September 24.

Némethné, G.A. (2010). A kis- és középvállalatok versenyképessége/The competitiveness of SMEs/. Közgazdasági Szemle /Economic Review/, 57, 181-193.

Neulinger, Á. (2007). Folyamatos megerösitést igénylö tanult fogyasztás - A társas környezet és a sportfogyasztás viszonya /Learned consumption that require continuous reinforcement - the relationship between social environment and sport consumption/. Doktori $(\mathrm{PhD})$ értekezés, BKÁE, Budapest /PhD-thesis, Budapest University of Economic Sciences/.

Oakley, B., Rhys, M. (2008). The Sport and Fitness Sector. New York: Routledge.

Paár, D. (2010). A magyar sportfogyasztás dinamikája /The dynamism of the Hungarian sports consumption/. VII. Országos Sporttudományi Kongresszus konferencia-kiadványa, Budapest: MSTT /VII. National Sport Science Congress Proceedings, Budapest: Hungarian Sports Science Association/.

Palócz, É. (2006). Egészségügy és versenyképesség /Healthcare and competitiveness/. Budapest: Kopint-Datorg Rt.

Pataki, Gy. (2007). A sport helye és jelentősége a magyar fiatalok életmódjában a 21. század küszöbén /The role and importance of sports in the lifestyle of Hungarian youth in the $21^{\text {st }}$ century/. Szakdolgozat, Budapest: BCE /Diploma work Corvinus University Budapest/.

Pawlikowska-Piechotka, A., Sawicka, K. (2013). Sport and Recreation Grounds: Urban Society Expectations. Physical Culture and Sport. Studies and Research, 57(1), 33-43. DOI: 10.2478/pcssr-2013-000.

Perényi, Sz. (2010). Value Priorities in Connection to Sport Participation. Physical Culture and Sport. Studies and Research, 48(1), 84-98. DOI: 10.2478/v10141-010-0009-x.

Pluhár, Zs., Keresztes, N. \& Pikó, B. (2003). Ép testben ép lélek. Középiskolások értékrendje fizikai aktivitásuk tükrében /Sound mind in a sound body. High school students' values and physical activity/. Magyar Sporttudományi Szemle /Hungarian Review of Sport Sciencel, 2, 29-33.

Polányi, G. (1998). A sportolás és a testmozgás társadalmi összefüggései/ Social context of sports and physical activities/. In P. Szívós \& Gy. Tóth István (1998). Társadalmi tény-kép /Social facts/. Budapest: TÁRKI

Secot, A. (2010). Sport and Physical Activities in the Czech Republic. Physical Culture and Sport. Studies and Research, 48(1), 44-65. DOI: 10.2478/v10141-010-0006-0.

Smith, A.C.T., Westerbeek, H.M. (2007). Sport as a Vehicle for Deploying Corporate Social Responsibility. Journal of Centrum Cathedra, 25, 43-54.

Suhrcke, M., McKee, M., Arce, R.S., Tsolova, S., Mortensen, Y. (2005). The contribution of health to the economy in the European Union. Office for Official Publications of the European Communities, Luxembourg.

Staines, N., Prince, I. \& Oliver, D. (2003). The Economic Impact of Physical Activity in Ontario. Retrieved November 21, 2006, from www.line.ca/lin/recource/html/econom.htm

Szabó, Á. (2012). A magyar szabadidösport müködésének vizsgálata. Piacok, értékteremtés, feladatok a szabadidösportban /An examination of the operation of Hungarian leisure sports system markets, value creation, and challenges in leisure sports/. Doktori (PhD) értekezés, Budapesti Corvinus Egyetem /PhD-thesis, Corvinus University Budapest/.

Wicker, P., Breuer, C., Pawlowsky, T. (2009). Promoting Sport for All to Age-specific Target Groups: the Impact of Sport Infrastructure. European Sport Management Quarterly, 9(2), 103-118. 
WHO. (2003). Health and development through physical activity and sport. Retrieved November 21, 2006, from http://whqlibdoc.who.int/hq/2003/WHO_NMH_NPH_PAH_03.2.pdf

AUTHOR'S ADDRESS: Ágnes Szabó Budapest Corvinus University

H-1147, Budapest, Zsolnay Vilmos u. 11. 1/1.

Hungary

E-mail: agnes.szabo2@uni-corvinus.hu 